\title{
Multiplex Inhibitor Screening and Kinetic Constant Determinations for Yeast Hexokinase Using Mass Spectrometry Based Assays
}

\author{
Hong Gao and Julie A. Leary \\ Department of Chemistry, University of California at Berkeley, Berkeley, California, USA
}

\begin{abstract}
An electrospray ionization mass spectrometry based assay was developed for kinetic measurements and inhibitor screening of yeast hexokinase. There is considerable discrepancy in the literature as to the accuracy of kinetic data obtained for hexokinase. In the assay described herein, the product, glucose 6-phosphate was directly monitored by ion trap mass spectrometry and quantified using an internal standard, 2 deoxy-glucose 6-phosphate. The kinetic parameters, $K_{\mathrm{M}}$ and $V_{\max }$ for the two substrates were determined without using a coupling enzyme as is normally employed in the traditional spectrophotometric assay for systems lacking a chromophore. In addition, hexokinase was successfully immobilized onto an amino-link gel, and a mock library was screened against the immobilized enzyme for the identification of possible inhibitors. After comparing the mass spectra of the library before and after incubation, trehalose 6-phosphate, ADP, and oxidized glutathione were differentiated from other weak or non-inhibitors. Inhibition behavior of ADP with respect to ATP was further evaluated with the ESI-MS assay and the value of $K_{\mathrm{i}}$ was determined. This ESI-MS assay was demonstrated to be both accurate and precise for determining kinetic constants and for identifying enzyme inhibitors. (J Am Soc Mass Spectrom 2003, 14, 173-181) @ 2003 American Society for Mass Spectrometry
\end{abstract}

$\mathrm{H}$ exokinase (HK, ATP-D-hexose-6-phosphotransferase) is a relatively nonspecific enzyme that catalyzes the transfer of a phosphate group from ATP to hexoses, such as D-glucose, D-mannose, and D-fructose. It acts as the first enzyme in the process of glycolysis by converting glucose into glucose 6-phosphate. Significant physiological roles for hexokinase have been demonstrated in glucose uptake/oxidation $[1,2]$, controlling the pentose phosphate pathway [3], and energy metabolism [4]. It is an important enzyme in glycolytic systems and has been involved with the design of metabolically significant compounds $[5,6]$. In studying the properties and functions of hexokinase, $K_{\mathrm{M}}$ and $V_{\max }$ for substrates and $K_{\mathrm{i}}$ for inhibitors are usually determined through steady-state kinetics measurements. Differences in substrate specificity and kinetic properties of isoforms of hexokinase can be used to distinguish disease-associated bacteria from nonpathogenic species [7]. The values of $K_{\mathrm{M}}$ and $V_{\max }$ have been applied to the differentiation of hexokinases from different sources of maize roots [8,9], and Teijon and co-workers $[10,11]$ studied the interaction of hexoki-

Published online January 24, 2003

Address reprint requests to Dr. J. A. Leary, Department of Chemistry, University of California at Berkeley, Berkeley, CA 94720-1460, USA. E-mail: leary@socrates.berkeley.edu nase with toxic metals by measuring the change in rate of glucose phosphorylation. However, there is a significant discrepancy among the values measured for the kinetic parameters. Table 1 is a brief summary of the values measured and the techniques used to obtain the various kinetic parameters [10, 12-18].

In general, kinetic measurements of $\mathrm{HK}$ are performed by spectrophotometric methods through the use of an auxiliary enzyme, glucose-6-phosphate dehydrogenase (GPDH). GPDH reduces glucose-6-phosphate with the conversion of $\mathrm{NADP}^{+}$to $\mathrm{NADPH}$, which is optically active. Since the presence of a coupling enzyme with additional substrates complicates the assay system and may interfere with the kinetic and inhibition study, a more direct assay is needed to facilitate kinetic measurements for HK. Recently, Golbik et al. [12] developed an acid-base dye-indicator linked assay to study this enzyme. In their method, they monitored the decrease in absorbance at $400 \mathrm{~nm}$ of $\mathrm{p}$-nitrophenolate due to the change in $\mathrm{pH}$ induced by the enzymatic reaction of hexokinase. However, the possible interference caused by addition of an organic compound is still a limitation in this method. Compared with the above spectrophotometric assay, significant advantages have been observed by using mass spectrometry coupled with soft ionization methods such as electrospray ionization (ESI) [19-33], and fast atom 
Table 1. Kinetic constants of HK from the literature

\begin{tabular}{|c|c|c|c|c|c|}
\hline $\begin{array}{l}\mathrm{K}_{\mathrm{M}}(\mathrm{mM}) \text { for } \\
\text { glucose }\end{array}$ & $\begin{array}{c}\mathrm{K}_{\mathrm{M}}(\mathrm{mM}) \text { for } \\
\text { ATP }\end{array}$ & $\mathrm{K}_{\mathrm{i}}(\mathrm{mM})^{\mathrm{a}}$ & Source of HK & Detection & References $^{\mathrm{b}}$ \\
\hline $0.235 \pm 0.041$ & $2.857 \pm 0.098$ & & Yeast, Sigma & Spectrophotometry & 10 \\
\hline $0.21 \pm 0.013$ & $0.071 \pm 0.011$ & & $\begin{array}{l}\text { S. cerevisiae, } \\
\text { self expression }\end{array}$ & $\begin{array}{l}\text { Acid-base dye- } \\
\text { indicator linked assay }\end{array}$ & 12 \\
\hline $0.138 \pm 0.002$ & $0.269 \pm 0.02$ & $\begin{array}{l}\text { ADP vs. ATP: } \\
\mathrm{K}_{\mathrm{ic}}=1.2 \pm 7.4 \%\end{array}$ & Yeast, sigma & $\begin{array}{l}\text { Trapped-flow } \\
\text { fluorescence }\end{array}$ & 13 \\
\hline 0.1 & $0.063 \pm 0.004$ & $\begin{array}{l}\text { Glc6P vs. Glc: } \\
\mathrm{K}_{\mathrm{ic}}=80 \pm 30 \\
\mathrm{~K}_{\mathrm{iu}}=200 \pm 15\end{array}$ & Yeast, sigma & Spectrophotometry & 14 \\
\hline $0.1097 \pm 0.022$ & $0.0886 \pm 0.0106$ & $\begin{array}{l}\text { ADP vs ATP: } \\
\mathrm{K}_{\mathrm{ic}}=1.45 \\
\text { ADP vs Glc: } \\
\mathrm{K}_{\mathrm{iu}}=5.56 ; \mathrm{K}_{\mathrm{ic}}=2.38\end{array}$ & $\begin{array}{l}\text { S. pombe } \\
\text { (fission yeast) } \\
\text { self-expression }\end{array}$ & Spectrophotometry & 15 \\
\hline HK1: 0.041 & Hk1: 0.09 & $\begin{array}{l}\text { ADP vs ATP } \\
\text { HK1: } \mathrm{K}_{\mathrm{ic}}=0.04\end{array}$ & $\begin{array}{l}\text { Potato tubers } \\
\text { Self-expression }\end{array}$ & Spectrophotometry & 16 \\
\hline HK2: 0.13 & HK2: 0.28 & $\begin{array}{l}\text { HK2: } \mathrm{K}_{\mathrm{ic}}=0.108 \\
\text { Glc6P vs Glc }\end{array}$ & & & \\
\hline HK3: 0.035 & HK3: 0.56 & $\mathrm{HK} 1: \mathrm{K}_{\mathrm{ic}}=4.1$ & & & \\
\hline & $0.21 \pm 0.02$ & & Yeast, sigma & Spectrophotometry & 17 \\
\hline 0.04 & & & Reticulocytes & & 18 \\
\hline 0.06 & & & Erythrocytes & & 18 \\
\hline 0.125 & & & Reticulocytes & & 18 \\
\hline
\end{tabular}

${ }^{\mathrm{a}} \mathrm{K}_{\mathrm{iu}}$ : non competitive inhibition constant; $\mathrm{K}_{\mathrm{ic}}$ : competitive inhibition constant.

${ }^{b}$ The number of references is the same as that in the text. Abbreviations used in this table: HK1, HK2, HK3: Different isoforms of hexokinase; Glc: Glucose; Glc6P: Glucose 6-phosphate; ADP: Adenosine 5'-diphosphate; ATP: Adenosine 5'-triphosphate.

bombardment (FAB) [23] to directly monitor product and/or substrate for kinetic studies. Our laboratory has developed a novel strategy for the determination of enzyme kinetics using electrospray ionization with an ion trap mass spectrometer [24]. By monitoring the formation of the product directly by mass, chromophogenic substrates or products are not necessary. In addition, a single-point normalization factor is generated through the use of an internal standard, therefore a calibration curve is not required and the total analysis time is approximately the same as that of the standard spectrophotometric assay. This method can be applied to study steady-state kinetics for most enzyme systems, provided that there is a mass change between the products and reactants and a suitable internal standard with comparable structure and ionization efficiency to the product or the substrate.

Herein we demonstrate the applicability of this ESI-MS assay in the kinetics study of hexokinase. The value of $K_{\mathrm{M}}$ and $V_{\max }$ for both substrates, glucose and ATP were determined by monitoring the product glucose 6-phosphate directly. In addition, a mock library of possible inhibitors was screened against HK immobilized onto amino-link gel following the IEMS (immobilized enzyme coupled with mass spectrometry) assay developed previously in this lab [25]. Several potent inhibitors were differentiated from weak or non-inhibitors. Using the above kinetic essay, the product inhibition behavior of ADP was also investigated and the value of $K_{\mathrm{i}}$ was determined. Thus, a mass spectrometry based assay is shown to be successfully utilized for both screening of potential ligand binders and for determin- ing kinetic constants for this important enzyme, hexokinase.

\section{Experimental}

\section{Materials}

All chemical reagents were obtained from commercial suppliers and used without further purification. Glucose, ATP in magnesium salt with Mg:ATP at 2:3, ADP, and all the compounds in the mock library as listed in Table 1 were from Sigma (St. Louis, MO). Yeast hexokinase (specific activity $120 \mathrm{u} / \mathrm{mg}$ protein) was purchased from Calbiochem (San Diego, CA). The amino link coupling gel (4\% cross-linked beaded agarose, 50\% slurry) and all the buffers used in the enzyme immobilization were purchased from Pierce (Rockford, IL).

\section{Instrumentation}

For the kinetic assay, a Finnigan (San Jose, CA) LCQclassic ion trap mass spectrometer equipped with ESI source for ionization was used. The sample was injected through a $5 \mu \mathrm{L}$ injection loop and delivered at a flow rate of $20 \mu \mathrm{L} / \mathrm{min}$ using a Harvard syringe pump. The capillary temperature and the spray voltage were kept at $175{ }^{\circ} \mathrm{C}$ and $3.5 \mathrm{kV}$, respectively. The product ion and the internal standard ion were monitored in the negative ion mode using selected ion monitoring (SIM). The chromatogram of the Qual Browser program (Thermo Finnigan) was used to monitor the delivery and ionization of each sample, and 20 scans for each chromato- 
gram peak were averaged to obtain the data for further quantification.

For inhibitor screening, a Bruker Daltonics (Billerica, MA) FT-ICR mass spectrometer equipped with an actively shielded 7 tesla superconducting magnet was used. Both nebulizing and drying gases were maintained at 25 psi. The solution of library components before and after incubation was infused into an Analytica electrospray source (Bradford, CT) at a rate of 2 $\mu \mathrm{l} / \mathrm{min}$ and ionized in the negative mode. Ions were externally accumulated in a radio frequency-only hexapole for 1-2 s before transfer into the ICR cell for analysis. Spectra were taken from an average of 32 transients composed of $1 \mathrm{M}$ data points using XMASS Version 5.0.10 (Bruker-Daltonics).

\section{Enzyme Kinetic Assay}

All kinetic experiments were carried out in $10 \mathrm{mM}$ ammonium acetate buffer, $\mathrm{pH} 7.5$, at room temperature with gentle rocking. Enzyme reactions were initialized by adding aliquots of HK solution, quenched after a certain amount of time in methanol containing the internal standard, and then analyzed directly on the LCQ in selected ion monitoring mode. To measure the $K_{\mathrm{M}}$ and $V_{\max }$ of the substrates, the concentration of one substrate was varied with the concentration of the other substrate kept at a constant saturated value. For inhibition studies of ADP with respect to ATP, a series of samples were prepared by varying the concentration of ATP and ADP with the concentration of glucose held constant. The concentration of the product glucose-6phosphate was measured through a single point normalization factor with the use of an internal standard. The value of $V_{\max }$ and $K_{\mathrm{M}}$ were calculated based on the saturation plot using the Grafit program (Erithacus Software Corp., Horley, Surrey, UK). The inhibition mode of ADP with respect to ATP was evaluated by analyzing the pattern of the double reciprocal plots. The $K_{i}$ value was calculated from the secondary plot [3].

\section{Inhibitor Screening}

The detailed procedure of immobilizing an enzyme onto amino-link gel and screening an inhibitor library against the immobilized enzyme has been described previously [25]. For hexokinase, the coupling buffer was $0.01 \mathrm{M}$ sodium phosphate, $\mathrm{pH} 7.5$, the quenching buffer was $0.01 \mathrm{M}$ ethanolamine $\mathrm{HCl}, \mathrm{pH} 7$, the washing buffer was $0.05 \mathrm{M}$ sodium chloride and the incubation buffer was $0.02 \mathrm{M}$ ammonium acetate, pH 7.5. Enzyme immobilization yields were determined by comparison of the amount of enzyme present before and after coupling to the gel [25]. Enzyme concentrations were determined by their absorbance at $280 \mathrm{~nm}$ using UV/ VIS spectrophotometry. The coupling efficiency was calculated according to $E \%=\left(1-A^{\prime} V^{\prime} / A^{0} V^{0}\right) \times 100 \%$, where $A^{\prime}$ and $V^{\prime}$ refer to the absorbance and volume of the enzyme solution washed from the column after

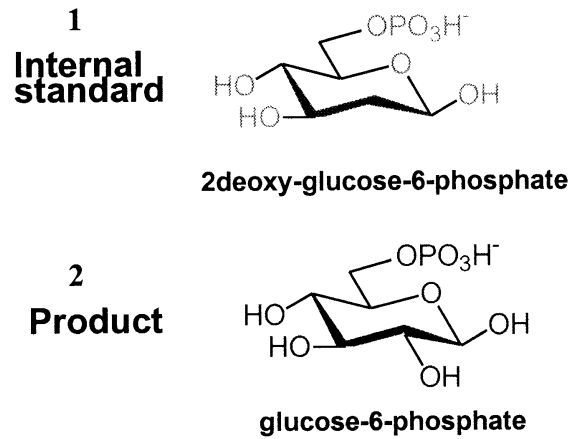

Figure 1. Structures of internal standard (1) and product (2).

coupling, while $A^{0}$ and $V^{0}$ refer to the values for the enzyme solution before immobilization onto the gel. The activity of immobilized enzyme was checked by incubating $250 \mu \mathrm{L}$ of $4 \mathrm{mM}$ glucose and $250 \mu \mathrm{L}$ of $8 \mathrm{mM}$ ATP with the gel for a 3 min reaction time and comparing the calculated catalytic constant with that obtained in solution phase. The inhibitor library was prepared at a final concentration of $4 \mu \mathrm{M}$ for each compound. A $250 \mu \mathrm{l}$ aliquot of the library solution was incubated with the immobilized enzyme for $1 \mathrm{~h}$ at room temperature with gentle rocking. The amount of immobilized enzyme was estimated to be $160 \mathrm{nmol}$, while the total amount of library components was $14 \mathrm{nmol}$, thus ensuring a molar excess of enzyme to ligands. The incubation mixture was centrifuged for $5 \mathrm{~min}$ at $3000 \mathrm{~g}$ and $40 \mu \mathrm{l}$ of supernatant was taken out and mixed with $160 \mu \mathrm{l}$ of $\mathrm{MeOH}$ for electrospray ionization.

\section{Results and Discussion}

Kinetic Measurements of $K_{M}$ and $V_{\text {max }}$ for the Substrates

For the quantification of glucose 6-phosphate, 2 deoxyglucose 6-phosphate was used as the internal standard. Based on the similarity in their structures, both compounds should possess similar ionization efficiencies. The structures for the internal standard (1) and the product (2) are shown in Figure 1. It is important to note that the instrument response is similar for both compounds, and thus a single point normalization factor could be used according to eq 1 :

$$
R=\left(I_{P} / I_{I S}\right) /([\text { Product }] /[\text { Internal standard }])
$$

where $I_{\text {IS }}$ is the intensity of the internal standard ion and $I_{\mathrm{p}}$ is the intensity of the product ion. The intensity ratio of the two ions is thus related to their concentration ratio through the normalization factor. $R$ was calculated to be 0.8 with a standard deviation of 0.05 when the concentration of glucose 6-phosophate varied from 0.5 to $50 \mu \mathrm{M}$ with the concentration of the internal standard held at $10 \mu \mathrm{M}$ (data not shown). This dynamic range was wide enough for product quantification in the kinetic measurements. By rearranging eq 1, the 

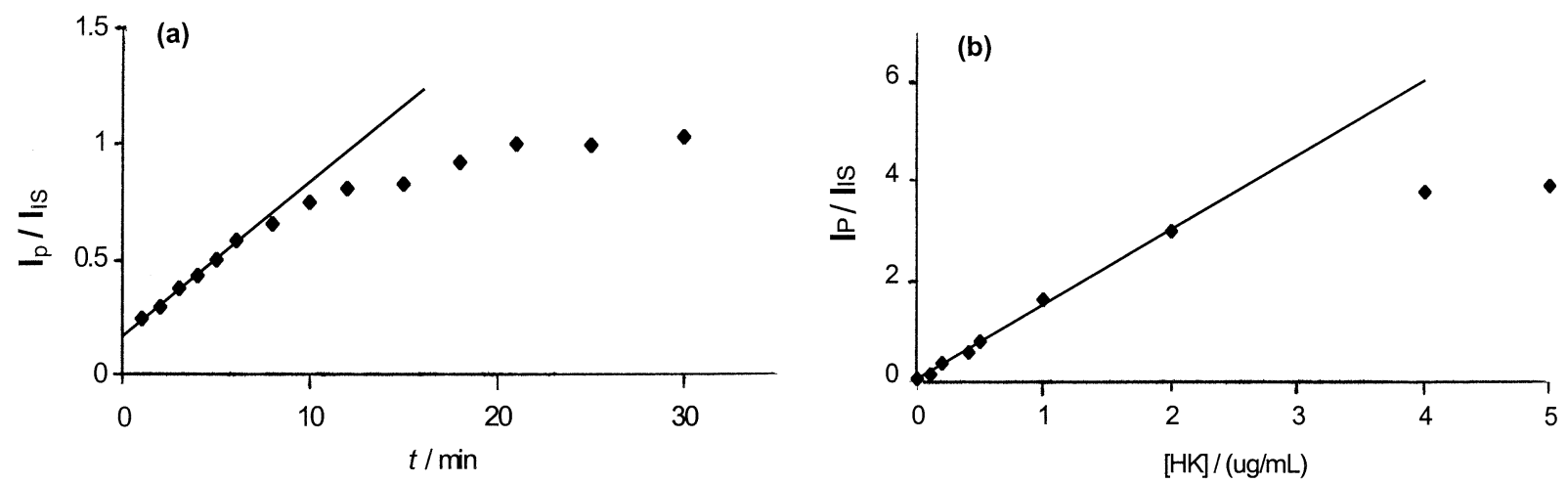

Figure 2. (a) Progress curve of product formation as a function of reaction time. The concentration of hexokinase was $1 \mu \mathrm{g} / \mathrm{mL}$. (b) Progress curve of product formation as a function of hexokinase concentration. The reaction time was $3 \mathrm{~min}$. For both experiments, the concentrations of glucose and ATP were kept at $0.1 \mathrm{mM}$ each.

product concentration can be determined according to eq 2 , and the initial velocity of the enzyme reaction is further calculated by dividing the product concentration by the reaction time.

$$
[\text { Product }]=\left(I_{P} / I_{I S}\right) \times[\text { Internal Standard }] / R
$$

Before measuring the kinetic parameters for hexokinase, two reaction progress curves were generated by monitoring the formation of product as a function of time (Figure 2a) and as a function of enzyme concentration (Figure $2 b$ ) to determine the optimum quenching time and enzyme concentration. To ensure the utilization of initial rate velocities for the calculation of $K_{\mathrm{M}}$ and $V_{\max }$ according to steady-state kinetics, the optimum quenching time and enzyme concentration should be within the linear region of each progress curve with the conversion percentage of the substrates as low as possible. Considering the lowest concentration of substrate needed for the determination of $K_{\mathrm{M}}$ $\left(0.2 K_{\mathrm{M}}\right)$, the detection limit by our ESI-MS assay, and the feasibility of manual quenching, an optimum quenching time of $3 \mathrm{~min}$ and optimum enzyme concen- tration of $0.4 \mu \mathrm{g} / \mathrm{mL}$ were selected. Under this optimized condition, a series of enzymatic reactions were carried out by varying the concentration of one substrate and holding the concentration of the other constant to obtain the values of $K_{\mathrm{M}}$. Figures $3 \mathrm{a}$ and $4 \mathrm{a}$ are the saturation plots of glucose and ATP respectively. The good linearity of the Lineweaver-Burk plots for both substrates shown in Figures $3 \mathrm{~b}$ and $4 \mathrm{~b}$ demonstrate the accuracy of application of steady-state kinetics in this assay. Average values of $K_{\mathrm{M}}$ and $V_{\max }$ for glucose were determined to be $0.13 \pm 0.02 \mathrm{mM}$ and $156.0 \pm 7.1 \mu \mathrm{mol} / \mathrm{mg} \cdot \mathrm{min}$, respectively. The apparent $K_{\mathrm{M}}$ value for ATP, when considering the sum of free ATP and ATP in magnesium complex as the substrate, was calculated to be $0.10 \pm 0.004 \mathrm{mM}$ and $V_{\max }$ for ATP was calculated to be $141.2 \pm 12.0 \mu \mathrm{mol} / \mathrm{mg} \cdot \mathrm{min}$. All kinetic parameters are reported based on three replicate experiments. The values obtained using the mass spectrometry based assay are well within the range of values obtained by other investigations (Table 1). Based on our experience, it would appear that the differences in ionic strength (i.e., $\mathrm{Mg}^{2+}$ concentration) may be responsible for the range of values measured.
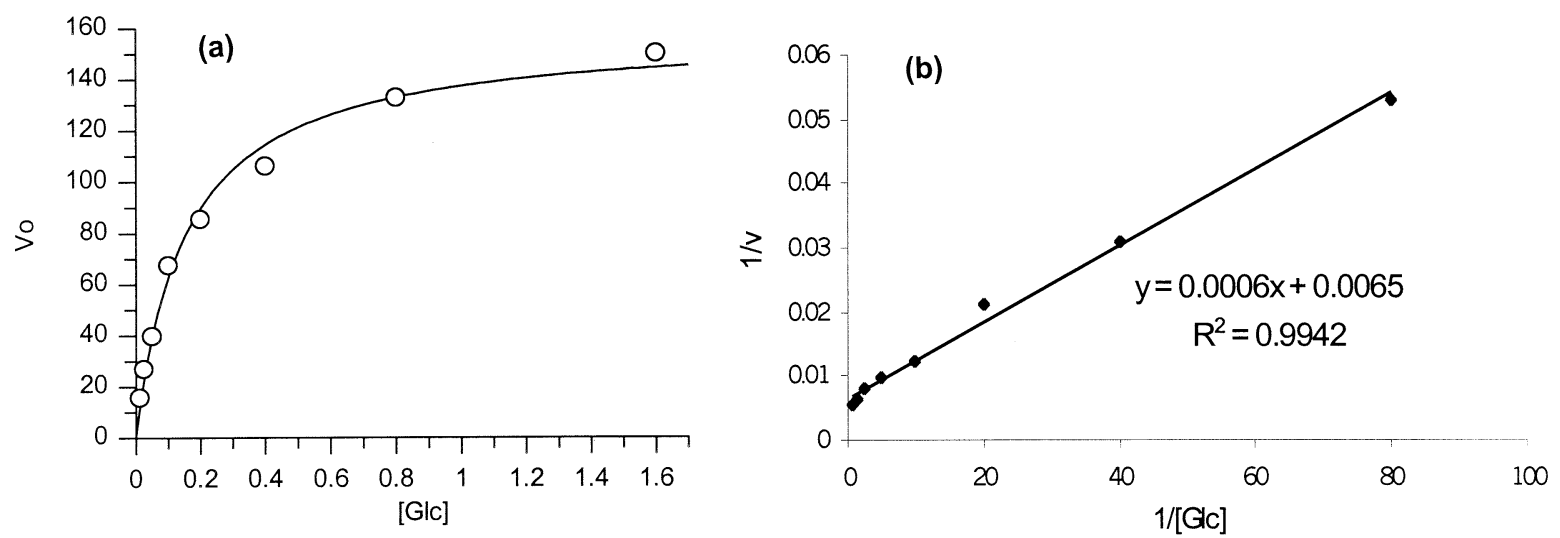

Figure 3. Saturation plot (a) and Lineweaver-Burk plot (b) for glucose. The concentration of glucose was varied from 0.0125 to $1.6 \mathrm{mM}$ and the concentration of ATP was kept at $1 \mathrm{mM}$; unit of glucose concentration is $\mathrm{mM}$; unit of velocity is $\mu \mathrm{mol} / \mathrm{mg} \cdot \mathrm{min}$. 

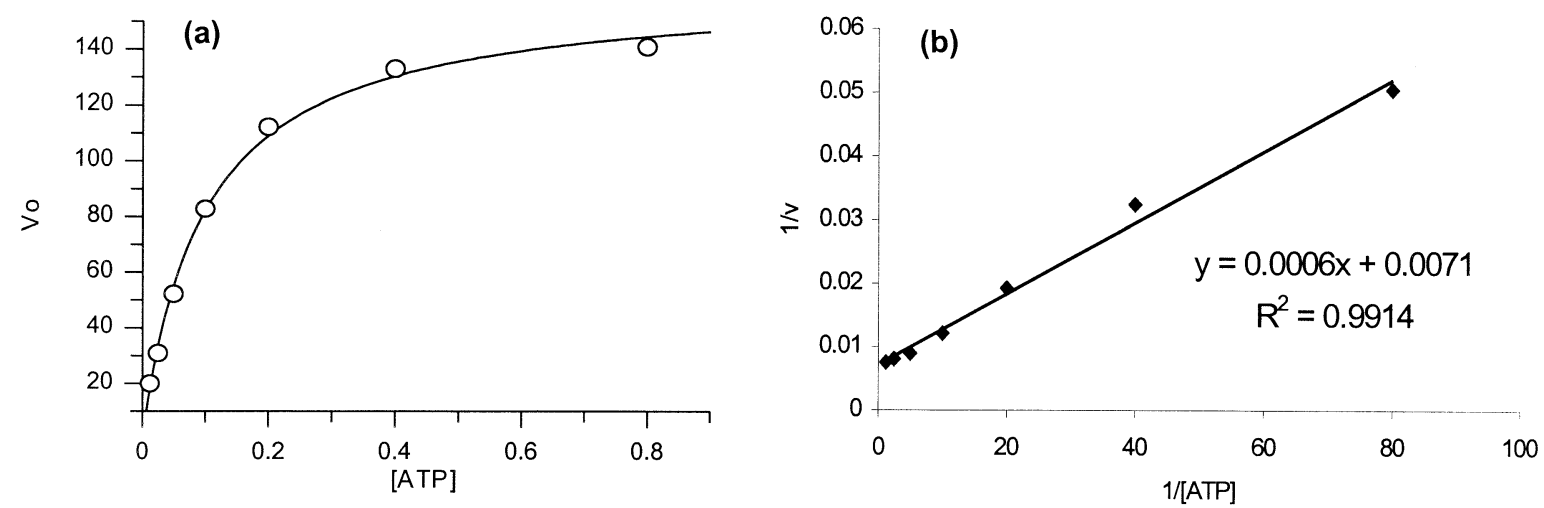

Figure 4. Saturation plot (a) and Lineweaver-Burk plot (b) of ATP. The concentration of ATP was varied from 0.0125 to $0.8 \mathrm{mM}$ and the concentration of glucose was kept at $5 \mathrm{mM}$; Unit of ATP concentration is $\mathrm{mM}$; unit of velocity is $\mu \mathrm{mol} / \mathrm{mg} \cdot \mathrm{min}$.

\section{Inhibitor Screening}

Several research groups have been developing novel inhibitors for hexokinase [3, 26-28], thus a multiplexing method for screening inhibitors would facilitate this process. Siuzdak and co-workers reported the application of quantitative electrospray mass spectrometry for screening libraries of inhibitors of enzymatic reactions of beta-1,4-galactosyltransferase [29] and glycosidases [30]. Recently, the IEMS assay developed in this lab has also been shown to be advantageous for fast inhibitor screening using several different enzymes [25, 31, 32]. In this assay, the enzyme is immobilized onto aminolink gel through reduced amination, and a library of compounds is incubated with the immobilized enzyme. Mass spectra are taken before and after incubation and compared. The applicability of this IEMS assay for hexokinase was tested using a mock library of known inhibitors and non-inhibitors, as listed in Table 2. Approximately $5 \mathrm{mg}$ of lyophilized HK was introduced onto the amino-link gel following the procedure specified in the experimental section. The immobilization efficiency was calculated to be $72 \%$ as described above.
The catalytic constant, $K_{\text {cat }}$ for the immobilized enzyme was calculated to be $1.67 \mathrm{~min}^{-1}$, while under the same conditions, a value of $1.06 \mathrm{~min}^{-1}$ was measured in the solution phase, thus indicating retention of catalytic activity.

Figure 5 is the negative mode FT-MS spectra for the library before and after incubation with the immobilized hexokinase. The ion corresponding to each component is labeled with its compound number as listed in Table 2. The ion at $\mathrm{m} / \mathrm{z} 633.1$ represents the sodium adduct of oxidized glutathione, while the ion at $\mathrm{m} / \mathrm{z}$ 382.5 corresponds to coenzyme A with two negative charges. The ions at $m / z 788.1$ and 810.1 correspond to coenzyme A with the adduction of one and two sodium, respectively. Here the advantage of using FT-MS instead of an ion trap for inhibitor screening was demonstrated. Due to the high resolution and high mass accuracy of FT-MS, each component in the library can be identified from a complicated matrix without ambiguity based on its measured mass, which was shown to be within $3 \mathrm{ppm}$ deviation from the calculated mass as shown in Table 2. Specifically, the compound

Table 2. Composition of the mock library and screening results

\begin{tabular}{|c|c|c|c|c|c|}
\hline Compound & $\begin{array}{c}\text { Elemental } \\
\text { composition }\end{array}$ & $\begin{array}{l}\text { Exact mass } \\
\text { at }[\mathrm{M}-\mathrm{H}]^{-}\end{array}$ & $\begin{array}{c}\text { Measured } \\
\text { mass by } \\
\text { FTMS }\end{array}$ & $\begin{array}{c}\text { Expected } \\
\text { binding } \\
\text { status }^{\mathrm{a}}\end{array}$ & $\begin{array}{r}\text { Percent } \\
\text { decrease }\end{array}$ \\
\hline 1 D-Ribose 5-phosphate & $\mathrm{C}_{5} \mathrm{H}_{11} \mathrm{O}_{8} \mathrm{P}$ & 229.0119 & 229.0116 & $\mathrm{~N}$ & 2.90 \\
\hline 2 Glucose 6-phosphate & $\mathrm{C}_{6} \mathrm{H}_{13} \mathrm{O}_{9} \mathrm{P}$ & 259.0224 & 259.0221 & $\mathrm{P}$ & 54.33 \\
\hline 3 Reduced glutathione & $\mathrm{C}_{10} \mathrm{H}_{17} \mathrm{~N}_{3} \mathrm{O}_{6} \mathrm{~S}$ & 306.0765 & 306.0762 & I & 54.46 \\
\hline 4 Glucose 1,6-diphosphate & $\mathrm{C}_{6} \mathrm{H}_{14} \mathrm{O}_{12} \mathrm{P}_{2}$ & 338.9888 & 338.9882 & $\mathrm{P}$ & 15.74 \\
\hline 5 Adenosine 5'-monophsophate (AMP) & $\mathrm{C}_{10} \mathrm{H}_{14} \mathrm{~N}_{5} \mathrm{O}_{7} \mathrm{P}$ & 346.0558 & 346.0554 & I & 51.43 \\
\hline 6 Uridine 5'-diphosphate (UDP) & $\mathrm{C}_{9} \mathrm{H}_{14} \mathrm{~N}_{2} \mathrm{O}_{122}$ & 402.9949 & 402.9941 & $\mathrm{P}$ & 51.86 \\
\hline 7 Trehalose 6-phosphate & $\mathrm{C}_{12} \mathrm{H}_{23} \mathrm{O}_{14} \mathrm{P}$ & 421.0753 & 421.0743 & I & 90.88 \\
\hline 8 Adenosine 5'-diphosphate (ADP) & $\mathrm{C}_{10} \mathrm{H}_{15} \mathrm{~N}_{5} \mathrm{O}_{10} \mathrm{P}_{2}$ & 426.0221 & 426.0216 & 1 & 91.31 \\
\hline 9 Guanosine 5'-diphosphate (GDP) & $\mathrm{C}_{10} \mathrm{H}_{15} \mathrm{~N}_{5} \mathrm{O}_{11} \mathrm{P}_{2}$ & 442.0171 & 442.0169 & $\mathrm{~N}$ & 31.27 \\
\hline 10 Uridine 5'-diphosphate-glucose (UDPG) & $\mathrm{C}_{15} \mathrm{H} 24 \mathrm{~N}_{2} \mathrm{O}_{17} \mathrm{P}_{2}$ & 565.0477 & 565.0473 & $\mathrm{P}$ & 62.46 \\
\hline 11 oxidized glutathione & $\mathrm{C}_{20} \mathrm{H}_{32} \mathrm{~N}_{6} \mathrm{O}_{12} \mathrm{~S}_{2}$ & 611.1447 & 611.1440 & 1 & 82.87 \\
\hline 12 Coenzyme A & $\mathrm{C}_{21} \mathrm{H}_{36} \mathrm{~N}_{7} \mathrm{O}_{6} \mathrm{P}_{3} \mathrm{~S}$ & 243.0275 & 766.105 & $\mathrm{~N}$ & 54.09 \\
\hline Internal standard: 2deoxy-glucose 6-phosphate & $\mathrm{C}_{6} \mathrm{H}_{12} \mathrm{O}_{8} \mathrm{P}$ & & 243.0273 & & \\
\hline
\end{tabular}

${ }^{\mathrm{a}} \mathrm{N}$ : noninhibitor; P: Possible inhibitor; I: Inhibitor. 


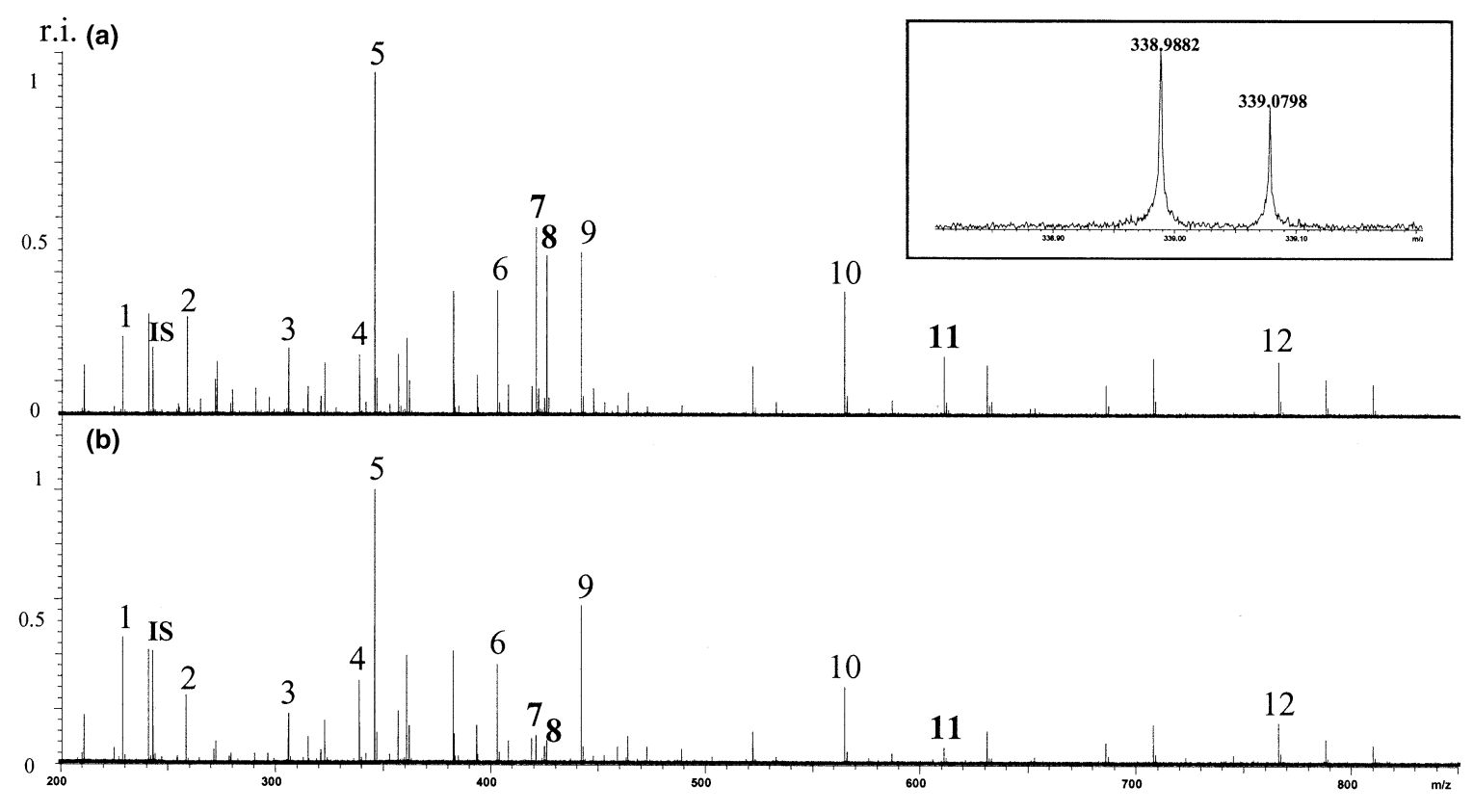

Figure 5. Negative mode FT-ICR spectra before (a) and after (b) incubation with the immobilized hexokinase. The inset is the expanded region for Compound 3 showing the resolution of isobaric ions.

glucose 1,6-diphosphate at $m / z 338.9882$ could be differentiated from an isobaric impurity at $\mathrm{m} / \mathrm{z} 339.0124$. Comparing these two spectra, it was observed that the relative ion abundance for several compounds, such as trehalose 6-phosphate and ADP, greatly decreased after incubation whereas several other compounds, such as ribose 5-phosphate and glucose 1,6-diphosphate, remained relatively the same. In order to quantitatively show the changes for each component after incubation, 2 deoxy-glucose 6-phosphate was again used as an internal standard, and the percent decrease was calculated using the relative abundance according to eq 3 .

$$
\Delta I \%=\left(I_{\text {after }} / I_{\text {before }}-1\right) \times 100 \%
$$

In this case, $I_{\text {after }}$ and $I_{\text {before }}$ is the ratio between the relative ion abundance of each component and that of the internal stand before and after incubation, respectively; $\Delta I \%$ is the percent decrease after incubation. The calculated result for each component is listed in Table 2, where trehalose 6-phophate, ADP, and oxidized glutathione could be identified as relatively strong inhibitors, which agrees with their expected binding properties [18, 33-35]. Ribose 5-phosphate and glucose 1,6-diphosphate appear to be relatively weak inhibitors or noninhibitors. A previous publication [36] showed that palmitoyl-coenzyme A was a non-inhibitor for yeast hexokinase, while in our experiments, the relative abundance of coenzyme A decreased more than 50\% after incubation. In general, this IEMS assay could successfully identify strong binders from weak binders with relatively easy manipulation. What is not apparent is whether ligands are specific or non-specific binders [31, 32]. In order to differentiate between these two types of binders, inhibition studies by kinetic experiments are required. The purpose of the multiplex screening approach is to identify " possible strong binders" and then verify that they are specific binders using the kinetics assay.

\section{Inhibition Study of ADP with Respect to ATP}

After demonstrating the binding affinity of the known product inhibitor ADP using the above screening procedure, the inhibition pattern and inhibition constant were investigated with the ESI-MS kinetic assay. Figure 6 is the chromatogram showing the intensity of the product as the concentration of ATP is increased from $0.025 \mathrm{mM}$ to $0.2 \mathrm{mM}$ at the following concentrations of ADP: $0 \mathrm{mM}, 0.25 \mathrm{mM}, 0.5 \mathrm{mM}$, and $0.75 \mathrm{mM}$. The decrease in the ion intensity of the product at higher ADP concentration clearly indicated its inhibition effect. By plotting the double reciprocal plots (first plot) of ATP at all the concentrations of ADP, the inhibition pattern can be identified. As shown in Figure 7a, all the double reciprocal lines intersect at the same point along the $y$ axis, which agrees with the previously reported competitive inhibition behavior of ADP with respect to ATP [18]. To further determine the inhibition constant $K_{\mathrm{i}}$ for ADP, a secondary plot, which illustrates the relationship between the slopes of the Lineweaver-Burk lines and the concentration of ADP, is shown in Figure $7 \mathrm{~b}$. The value of $K_{\mathrm{i}}$ can be determined according to the equation for the secondary plot (eq 4), which is calculated to be $0.122 \pm 0.003 \mathrm{mM}$ in this case.

The secondary plot: ${ }^{1 \text { st }}$ slope $=\left(K_{M} / V_{\text {max }}\right)$

$$
\cdot\left(1+[A D P] / K_{i}\right)
$$




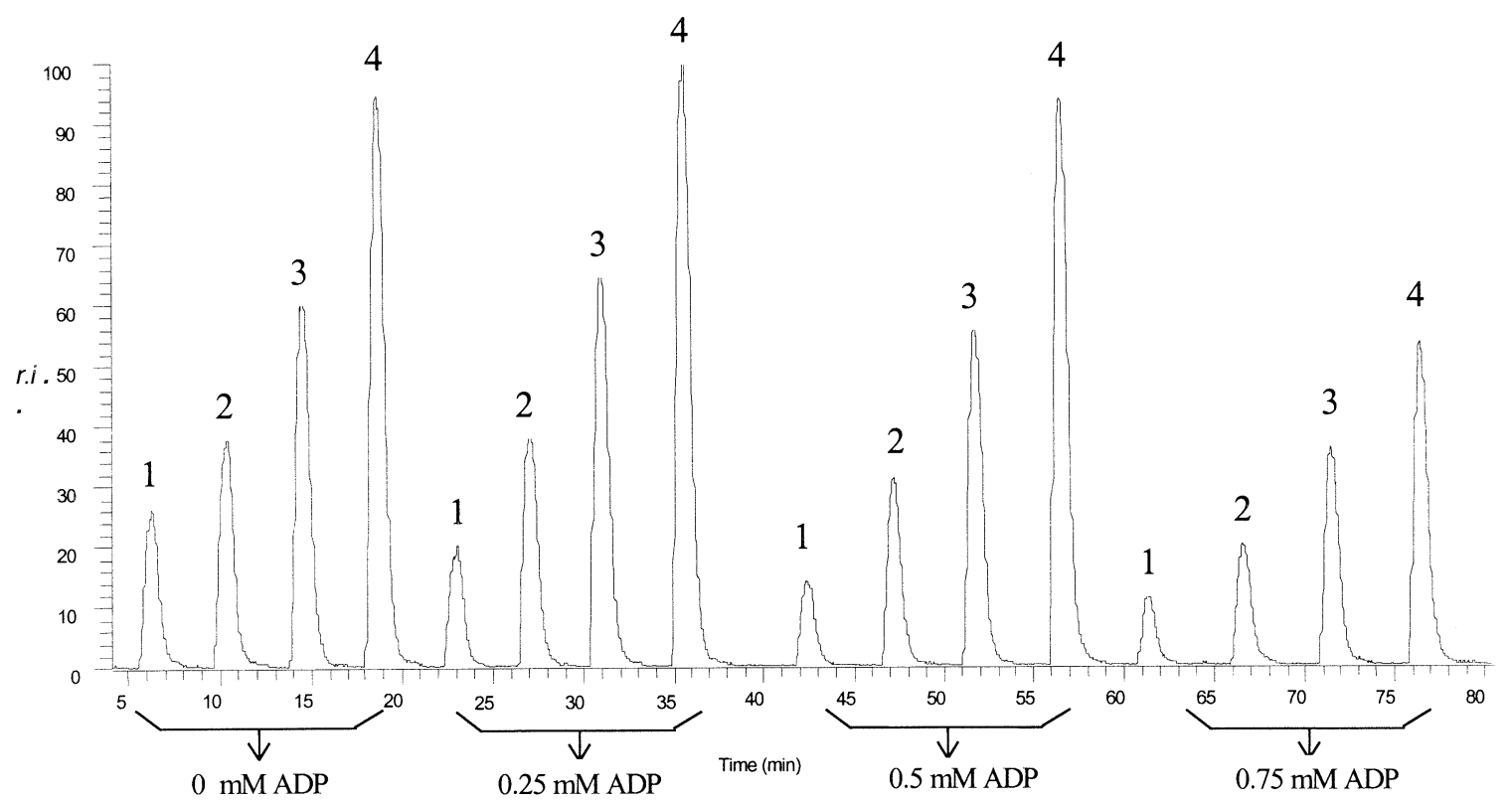

Figure 6. Chromatogram obtained from the inhibition experiments by monitoring the ion intensity of the product. Within each series of samples, the concentration of ADP was varied from 0 to $0.75 \mathrm{mM}$. The concentration of ATP was 0.025 (1), 0.05 (2), 0.1 (3), and 0.2 (4) mM.

$$
\begin{aligned}
{ }^{2 \text { nd }} \text { Intercept } /{ }^{2 \text { nd }} \text { Slope }= & \left(K_{M} / V_{\max }\right) / \\
& \left\{\left(K_{M} / B_{\max }\right) / K_{i}\right\}=K_{i}
\end{aligned}
$$

The difference between the $K_{\mathrm{i}}$ values reported here and those from the literature $[14,15,18]$ may be due to the difference in the buffer conditions. In our kinetic measurements, the magnesium salt of ATP with a Mg:ATP ratio of 2:3 was used as the second substrate, and no additional $\mathrm{Mg}^{2+}$ was added into the buffer, while in other spectrophotometric measurements, a buffer system with constant concentration of $\mathrm{Mg}^{2+}$ was usually used $[14,15]$. The effects of $\mathrm{Mg}^{2+}$ concentration on the kinetics of this enzyme are currently under investigation in our laboratory.

\section{Conclusion}

A novel ESI-MS kinetics assay has been successfully applied to hexokinase. Kinetic constants, $K_{\mathrm{M}}$ and $V_{\max }$ for the two substrates of HK were determined. HK was successfully immobilized onto amino-link gel through reduction amination with retention of catalytic activity. Known inhibitors, including ADP, were identified by screening a mock library against the immobilized HK and analyzed using ESI-FTMS. Competitive inhibition behavior of ADP with respect to ATP was demonstrated and the value of $K_{\mathrm{i}}$ was determined. The kinetic parameters for hexokinase obtained here are within the range of values previously reported, and are believed to be accurate. Since no chromophore or radio labels are required in the ESI-MS assay, and the analysis time is comparable to standard UV techniques, the mass spectrometry-based assay is expected to be more convenient and accurate than traditional methods, especially for those enzymes with no UV active substrates or products. In addition, if combined with fast mixing techniques, such as stopped flow, the ESI-MS assay can be further applied to monitor the enzymatic reaction con-
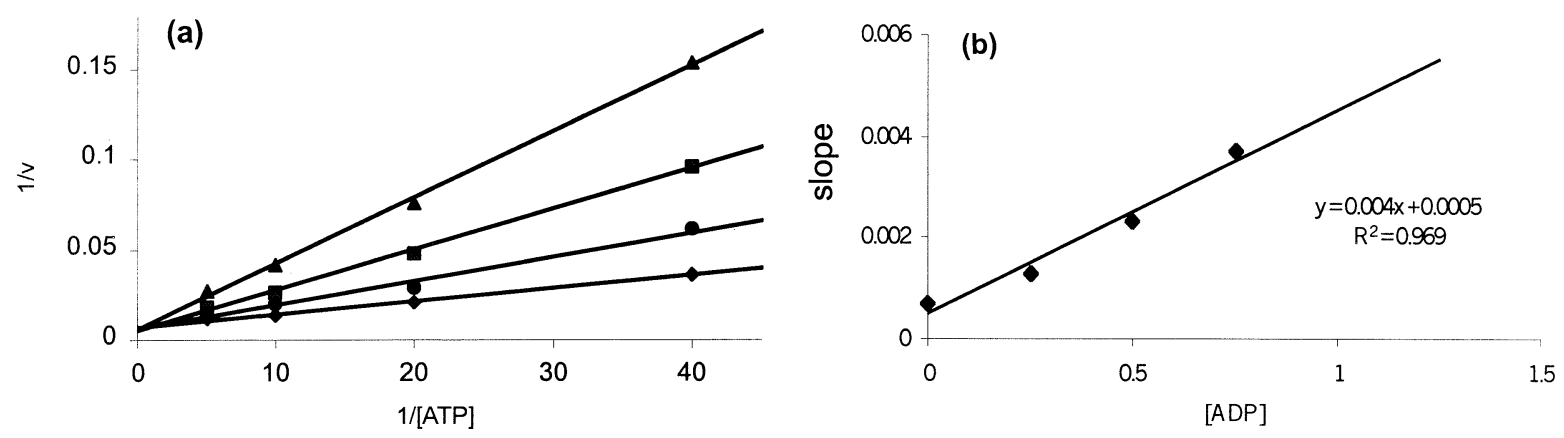

Figure 7. (a) Double reciprocal plots showing the inhibition behavior of ADP. From the bottom to the top lines, the concentration of ADP was $0,0.25,0.5$, and $0.75 \mathrm{mM}$. (b) Secondary plot for the calculation of $K_{\mathrm{i}}$. Unit of ATP concentration is $\mathrm{mM}$; unit of velocity is $\mu \mathrm{mol} / \mathrm{mg} \cdot \mathrm{min}$. 
tinously. In this way, the initial velocity is determined from the slope in the real time plot of the product formation or substrate consumption, which is more accurate than the analysis of quenched samples. Through stopped-flow ESI-MS assay, pre-steady state kinetics is also achievable to measure transient rate constants by following the formation of enzyme-substrate complex in real time. Future work in this laboratory will be focused on the inhibition study of synthetic inhibitors and applying the technique to other phosphotransferases that are, thus far, not well characterized.

\section{Acknowledgments}

The authors gratefully acknowledge the grant of NIH, GM 63581 for funding this work.

\section{References}

1. Lowry, O. H.; Passonneau, J. V. Relationships Between Substrates and Enzymes in Glocolysis in Brain. J. Biol. Chem. 1964, 239, 31-42.

2. Bisson, L. F.; Franenkel, P. F. Involvement of Kinases in Glucose and Fructose Uptake by Saccharomyces cerevisiae. Proc. Natl. Acad. Sci. U.S.A. 1983, 80, 1730-1734.

3. Willson, M.; Perie, J. Inhibition of Yeast Hexokinase: A Kinetic and Phosphorus Nuclear Magnetic Resonance Study. Spectrochimica Acta Part A 1999, 55, 911-917.

4. Depre, C.; Rider, M. H.; Hue, L. Mechanisms of Control of Heart Glycolysis. Eur. J. Biochem. 1998, 258, 277-290.

5. Willson, M.; Lauth, N.; Perie, J.; Callens, M; Opperdoes, F. R. Inhibition of Clyceraldehyde-3-phosphate Dehydrogenase by Phosphorylated Epoxides and $\alpha$-Enones. Biochem. 1994, 33, 214-220.

6. Perie, J.; Alric, I.; Blonski, C. Inhibition of the Glycolytic Enzymes in the Trypanosome-an Approach in the Development of New Leads in the Therapy of Parasitic Diseases. Pharmacol. Therapeut. 1993, 60, 347-365.

7. Kroschewski, H.; Ortner, S.; Steipe, B.; Scheiner, O.; Wiedermann, G.; Duchene, M. Differences in Substrate Specificity and Kinetic Properties of the Recombinant Hexokinases HXK1 and HXK2 from Entamoeba histolytica. Mol. Biochem. Parasitol. 2000, 105, 71-80.

8. Calina, A. C.; Logullo, E. F.; Souza, G. L.; Rezende, W. S. Sugar Phophorylation Modulates ADP Inhibition of Maize Mitochondrial Hexokinase. Physiol. Plantarum 1999, 105, 17-23.

9. Galina, A.; Reis, M.; Albuquerque, M. C. Different Properties of the Mitochondrial and Cytosolic Hexokinases in Maize Roots. Biochem. J. 1995, 309, 105-112.

10. Socorro, J. M.; Olmo, R. C.; Blanco, M. D.; Teijon, J. M. Analysis of Aluminum-Yeast Hexokinase Interaction: Modifications on Protein Structure and Functionality. J. Protein Chem. 2000, 19, 199-208.

11. Teijon, C.; Olmo, R.; Socorro, J. M.; Blanco, M. D.; Romero, A.; Teijon, J. M. Lead-Yeast Hexokinase Interaction: Modifications to Protein Structure Caused by the Metal. Polym. Int. 2001, 50, 822-827.

12. Golbik, R.; Naumann, M.; Otto, A.; Muller, E. C.; Behlke, J.; Reuter, R.; Hubner, G.; Kriegel, T. Regulation of Phosphotransferase Activity of Hexokinase 2 from Saccharomyces cerevisiae by Modification at Serine-14. Biochem. 2001, 40, 1083-1090.

13. Hillard, S. W.; Stewart, K. K. A Bypass Trapped-Flow Analysis System Evaluation of Enzyme Kinetic Parameters with a
Coupled Enzyme Assay and Fluorescence Detection. Talanta 1998, 45, 507-512.

14. Viola, R. E.; Raushel, F. M.; Rendina, A. R.; Cleland, W. W. Substrate Synergism and the Kinetic Mechanism of Yeast Hexokinase. Biochem. 1982, 21, 1295-1302.

15. Tsai, S. C.; Chen, Q. Purification and Kinetic Characterization of Hexokinase and Glucose-6-Phosphate Dehydrogenase from Schizosaccharomyces pombe. Biochem. Cell. Biol. 1998, 76, 107113.

16. Renz, A.; Stitt, M. Substrate Specificity and Product Inhibition of Deterrent Forms of Fructokinases and Hexokinases in Developing Potato Tubers. Planta 1993, 190, 166-175.

17. Guerra, R.; Bianconi, M. L. Increased Stability and Catalytic Efficiency of Yeast Hexokinase Upon Interaction with Zwitterionic Micelles. Kinetics and Conformational Studies. Biosci. Rep. 2000, 20, 41-48.

18. Schomburg, D.; Stephan, D. Enzyme Handbook, Vol XIII. Springer Verlag, Heidelberg, Berlin, Germany, 1997, pp. $1-9$.

19. Lee, E. D. 1.; Mueck, W.; Henion, J. D. Real-Time Reaction Monitoring by Continuous Introduction Ion-Spray Tandem Mass Spectrometry. J. Am. Chem. Soc. 1989, 111, 4600-4604.

20. Bothner, B.; Chavez, R.; Wei, J.; Strupp, C.; Phung, Q.; Schneemann, A.; Siuzdak, G. Monitoring Enzyme Catalysis with Mass Spectrometry. J. Biol. Chem. 2000, 275, 13455-13459.

21. Norris, K. T.; Whitelegge, J. P.; Faull, K. F.; Toyokuni, T. Analysis of Enzyme Kinetics Using Electrospray Ionization Mass Spectrometry and Multiple Reaction Monitoring: Fucosyltransferase V. Biochem. 2001, 40, 3774-3779.

22. Zechel, D. L.; Konermann, L.; Withers, S. G.; Douglas, D. J. Pre-Steady State Kinetic Analysis of an Enzymatic Reaction Monitored by Time-Resolved Electrospray Ionization Mass Spectrometry. Biochem. 1998, 37, 7664-7669.

23. Newton, R. P.; Bayliss, M. A.; Khan, J. A.; Bastani, A.; Wilkins, A. C.; Games, D. E.; Walton, T. J.; Brenton, A. G.; Harris, F. M. Kinetic analysis of cyclic CMP-specific and multifunctional phosphodiesterases by quantitative, positive-ion, fast-atom bombardment mass spectrometry. Rapid Commun. Mass Spectrom. 1999, 13, 574-584.

24. Ge, X.; Sirich, T. L.; Beyer, M. K.; Desaire, H.; Leary, J. A. A Novel Strategy for the Determination of Enzyme Kinetics Using Electrospray Ionization with an Ion Trap Mass Spectrometer. Anal. Chem. 2001, 73, 5078-5082.

25. Cancilla, M. T.; Leavell, M. D.; Chow, J.; Leary, J. A. Mass Spectrometry and Immobilized Enzymes for the Screening of Inhibitor Libraries. Proc. Natl. Acad. Sci. U.S.A. 2000, 97, 12008-12013.

26. Willson, M.; Alric, I.; Perie, J.; Sanejouand, Y. H. Yeast Hexokinase Inhibitors Designed from the 3-D Enzyme Structure Rebuilding. J. Enz. Inhibit. 1997, 12, 101-114.

27. Newgard, C. B.; Han, H. P.; Becker, T. C.; Wilson, J. E. Inhibitors of Hexokinase Function for Increasing Levels of Synthesis of Insulin in Producer Cells. PCT Int. Appl. 1997; pp 254.

28. Yonekura, K.; Eto, Y.; Yokoyama, I.; Matsumoto, A. Inhibition of Carnitine Synthesis Modulates Protein Contents of the Cardiac Sarcoplasmic Reticulum $\mathrm{Ca}^{2+}$-ATPase and Hexokinase Type I in Rat Hearts with Myocardial Infarction. Basic Res. Cardiol. 2000, 95, 343-348.

29. Takayama, S.; Martin, R.; Wu, J. Y.; Laslo, K.; Siuzdak, G.; Wong, C. H. Chemoenzymatic Preparation of Novel Cyclic Imine Sugars and Rapid Biological Activity Evaluation Using Electrospray Mass Spectrometry and Kinetic Analysis. J. Am. Chem. Soc. 1997, 119, 8146-8151.

30. Wu, J. Y.; Takayama, S.; Wong, C. H.; Siuzdak, G. Quantitative Electrospray Mass Spectrometry for the Rapid Assay of Enzyme Inhibitors. Chem. Biol. 1997, 4, 653-657. 
31. Armstrong, J. I.; Ge, X.; Verdugo, D. E.; Winans, K. A.; Leary, J. A.; Bertozzi, C. R. A Library Approach to the Generation of Bisubstrate Analogue Sulfotransferase Inhibitors. Org. Lett. 2001, 3, 2657-2660.

32. Verdugo, D. E.; Cancilla, M. T.; Ge, X.; Gray, N. S.; Chang, Y. T.; Schultz, P. G.; Negishi, M.; Leary, J. A.; Bertozzi, C. R. Discovery of Estrogen Sulfotransferase Inhibitors from a Purine Library Screen. J. Med. Chem. 2001, 4, 2683-2686.

33. Panneman, H.; Ruijter, G. J. G.; Broeck, H. C.; Visser, J. Cloning and Biochemical Characterisation of Aspergillus niger Hexokinase-The Enzyme is Strongly Inhibited by
Physiological Concentration of Trehalose-6-Phosphate. Eur. J. Biochem. 1998, 258, 223-232.

34. Fornaini, G.; Dacha, M.; Magnani, M.; Stocchi, V. Hexokinase from Rabbit Red Blood Cells. Methods Enzymol. 1982, 90, 3-10.

35. Liu, S. S.; Witkovsky, P.; Yang, C. Y. Retinal HexokinaseKinetic Properties and Effect of Cyclic 3',5'-Adenosine-Monophosphate. J. Neurochem. 1983, 41, 1694-1701.

36. Vandercammen, A.; van Schaftingen, E. Competitive Inhibition of Liver Glucokinase by its Regulatory Protein. Eur. J. Biochem. 1991, 200, 545-551. 